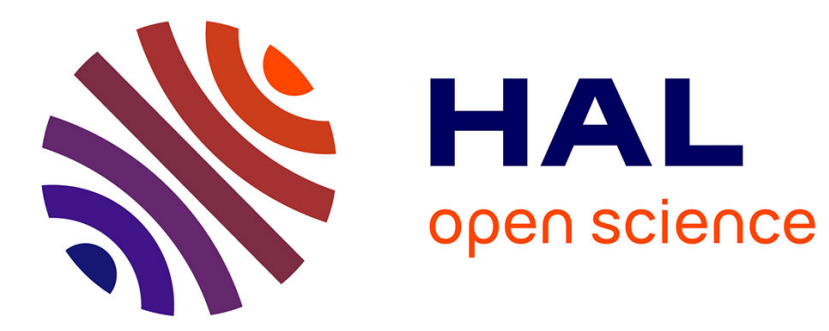

\title{
Water pressure enhanced sintering of alkaline-earth perovskite ceramics
}

\author{
Aneta Slodczyk, O Lacroix, Philippe Colomban
}

\section{To cite this version:}

Aneta Slodczyk, O Lacroix, Philippe Colomban. Water pressure enhanced sintering of alkalineearth perovskite ceramics. Ceramics International, 2015, 41 (9, Part A), pp.11528-11533. 10.1016/j.ceramint.2015.05.082 . hal-01155482

\section{HAL Id: hal-01155482 https://hal.sorbonne-universite.fr/hal-01155482}

Submitted on 26 May 2015

HAL is a multi-disciplinary open access archive for the deposit and dissemination of scientific research documents, whether they are published or not. The documents may come from teaching and research institutions in France or abroad, or from public or private research centers.
L'archive ouverte pluridisciplinaire HAL, est destinée au dépôt et à la diffusion de documents scientifiques de niveau recherche, publiés ou non, émanant des établissements d'enseignement et de recherche français ou étrangers, des laboratoires publics ou privés. 
Water Pressure Enhanced Sintering of Alkaline-Earth Perovskite ceramics

Aneta Slodczyk $^{1,2}$, O. Lacroix ${ }^{3}$, Philippe Colomban $^{1,2^{*}}$

${ }^{1}$ Sorbonne Universités, UPMC Univ Paris 06, UMR 8233, MONARIS, c49 4 Place Jussieu, F-75005,

Paris, France

${ }^{2}$ CNRS, UMR 8233, MONARIS, UPMC, 4 Place Jussieu, F-75005, Paris, France

${ }^{3}$ AREVA NP, Université de Montpellier, F-34095 Montpellier Cedex 5, France

* corresponding author philippe.colomban@upmc.fr

Tel : 33144272785

Fax: 33144273021 
Abstract

The alkaline earth- based perovskite ceramics are potential electrolytes for components of electrolysers, fuel cells and $\mathrm{CO}_{2} /$ syngas converters. Their high refractariness is an advantage from the chemical stability point of view but involves high sintering temperature $\left(>1500^{\circ} \mathrm{C}\right)$, detrimental to the co-sintering procedure required to assemble device components. Since the presence of protonic species is not intrinsic to the perovskite structure, the $\mathrm{Ln}$ - modified perovskites have to be successfully protonated by exposition of dense (95-99\% theoretical density) ceramic pieces to (pressurized) water. We demonstrate that densification of a $A Z r_{1-x} \operatorname{Ln}_{x} \mathrm{O}_{3-\delta}$ ceramic can be enhanced by prior exposition of 1200 to $1300^{\circ} \mathrm{C}$ pre-fired (porous) ceramics to high water pressure using an autoclave. Autoclave temperature and treatment duration are considered. Thermal expansion measurements reveal that the protonation $\left(200-300^{\circ} \mathrm{C}\right.$ under $15-80$ bar of water vapour) of previously fired $\left(70-80 \%\right.$ of the theoretical density) porous perovskite body $\left(\operatorname{SrZr}_{1-x} \mathrm{Yb}_{x} \mathrm{O}_{3}, \mathrm{x}=0.1\right)$ enhances the sintering and allows densification at lower temperature. The gain in temperature reaches $200-300^{\circ} \mathrm{C}$. IR and Raman studies show that the film formed on surface consists of (hydrated) alkali-earth oxyhydroxides. Sintering enhancement is assigned to the modification of the material structure close to the grain surface/boundary and to the enhancement of tions mobility at the grain surface/interface.

Keywords : proton, sintering, perovskite, ceramic, sol-gel 


\section{INTRODUCTION}

Since decades, the oxygen deficient $A B_{1-x} Z_{x} O_{3-\delta}$ perovskite ceramics [1-7] are considered as a potential base of Hydrogen economy [8]. Namely, they can be used as electrolytic membranes (electrolyte [1-5,8,9] and (part of) electrodes $[6,7,10,11]$ ) of fuel cells, electrolysers, gas separation membranes and/or $\mathrm{CO}_{2} /$ Syngas convertors. These perovskites are oxygen ion conductors above $700 / 800^{\circ} \mathrm{C}$ and proton conductors between 400 and $600^{\circ} \mathrm{C}$. The presence of protonic species is not intrinsic to the perovskite structure. Consequently, the $\mathrm{ABO}_{3}$ perovskite have to be first modified by substituting the $\mathrm{B}^{4+}$ ion by $\mathrm{Ln}^{3+}$ one in order to create oxygen vacancies and then exposed to water that allows the partial filling of vacancies by oxygen ions and the incorporation of protons $[12,13]$. In the case of dense (95-99\% theoretical density) ceramic pellets, the most efficient proton-incorporation procedure is the exposition to (pressurized) water [9,13-17]. Such protonation process requires a few days of treatment at middle or high temperature [14]. Note, many literature data deal with powder perovskites (see review in |18]) - due to their important active surface the protonation seems to be easier and faster, however simultaneously the carbonation and hydroxylation reactions are enhanced (see $[14,16,17]$ for more details).

The very important refractority of Zr-based perovskites is an advantage from the chemical stability point of view but requires high sintering temperatures $\left(>1450^{\circ} \mathrm{C}\right)[19]$. Such a high sintering temperature is however detrimental to the co-sintering procedure required to associate electrolyte, anode, cathode and eventually other materials (substrate, interconnects, current collectors, etc.) to form the core of the above mentioned electrochemical devices. In particular, electrode materials based on less refractory transition metals because of their specific catalytic properties ( $\mathrm{Co}, \mathrm{Ni}$, $\mathrm{Fe}$, etc.) cannot support such high temperatures. Different methods to lower the sintering temperature have been proposed: i) decreasing the grain size as issued from sol-gel routes (it is difficult to have grain smaller than $0.1 \mu \mathrm{m}$ ) [20-23], ii) doping (segregation at grain boundary is common) and iii) adding a temporary liquid phase such as $\mathrm{B}_{2} \mathrm{O}_{3}$, fluoride or earth alkali excess [24]. However; the incomplete control of these processes may have detrimental influence on proton conduction performances. Note, important addition of different elements is not recommended when a high electrochemical stability is required $[24,25]$. 
Previous studies on various oxide compositions prepared by hydrolysis-polycondensation, the alkoxide sol-gel route, demonstrated that densification of the material is driven by the departure of protonic species that enhances the atom diffusion at the grain surface/interface [26-29]. We present here a preliminary comparison of the sintering behaviour of pre-fired porous perovskite ceramics with or without preliminary protonation in order to determine the effect of protonation on the sintering properties.

\section{MATERIAL AND METHODS}

Reference Yb-substituted strontium zirconate ceramic pellets (diameter $=8 \mathrm{~mm}$ : thickness $\sim 1.5 \mathrm{~mm}$ ) were prepared from nitrate reagents as described in refs [24,25]. The chemically prepared powder (coprecipitation) was calcined at $700^{\circ} \mathrm{C}$ (grain size around $300 \mathrm{~nm}$, specific area $\sim 8 \mathrm{~m}^{2} / \mathrm{g}$ ). Then, the powder was milled in order to eliminate the agglomerates, dried and finally pressed under $300 \mathrm{MPa}$.

The green density was $\sim 50 \%$. The sintering was performed between 1450 and $1650^{\circ} \mathrm{C}$ for 6 to 4 hours under controlled variable atmosphere (Hydrogenated argon and air) as a function of the target densification. An additional isothermal treatment of $3 \mathrm{~h}$ was made at $900^{\circ} \mathrm{C}$ in order to eliminate traces of organic additives. The density measured by the Archimedes' method ranges from 90 to $98 \%$ of the theoretical density depending on the dwell temperature and duration of the thermal treatment. Porous ceramics were prepared following essentially the same procedure but stopping the sintering step at 1200 or $1300^{\circ} \mathrm{C}$. Their densities are 60 and $70 \%$, respectively. The composition $\operatorname{SrZr}_{1-x} \mathrm{Yb}_{\mathrm{x}} \mathrm{O}_{3-\delta}(\mathrm{x}=0.05$ to 0.15 , here after noted $5 \mathrm{Yb}: \mathrm{SZ}, 10 \mathrm{Yb}: \mathrm{SZ}$ etc.) was routinely controlled by chemical analysis. In order to perform different measurements/treatments on the same sample, each ceramic pellet was broken in 4 pieces. The thermal expansion measurements were carried out under Ar atmosphere between $25^{\circ} \mathrm{C}$ and $1400^{\circ} \mathrm{C}\left(10^{\circ} \mathrm{C} / \mathrm{min}\right.$ on both heating and cooling). Setaram Setsys 1750 dilatometer (France) equipped with a cylindrical alumina sensor rod and support was used. The vertical design allowed non-oscillating loading between 2 and 150 grams. [30] The $10 \mathrm{~g}$ load was selected in this study. Note such a charge value allows assuring a good contact but limits the creeps. The diameter of the contact surface was estimated to be of the order of $\sim 5 \mathrm{~mm}$. Additional measurements between $25^{\circ} \mathrm{C}$ and $700^{\circ} \mathrm{C}$ were made with an amorphous silica sensor rod and support in order to enhance the detection of eventual structural modifications of the host perovskite structure. 
TGA was performed between 40 an $1000^{\circ} \mathrm{C}$ using a Setaram Setsys Evolution thermobalance. The use of Pt-crucible and He- atmosphere allows significant enhancement of the measurement accuracy.

The details related to the recording of Raman and IR spectra can be found in our previous articles [1217].

Various treatments under high water pressure were performed using home designed temperature and pressure controlled autoclaves [12-15]. $\mathrm{CO}_{2}$-free water was used in order to limit the carbonation. The homogeneity of the protonation was controlled by Raman profilometry, an indirect method calibrated by neutron elastic scattering and neutronography [12-14]. 96 hour duration of the autoclave treatment was necessary to obtain an homogeneous protonation in the case of $\sim 1.5 \mathrm{~mm}$ thick pellet.

\section{RESULTS}

Figure 1 compares the thermal expansion curves recorded under Ar atmosphere on as received, $\mathrm{Yb}: \mathrm{SZ}$ non-protonated ceramic pellet previously fired at $1450^{\circ} \mathrm{C}$ (densification $~ 95 \%$ ) as well as on various protonated $\mathrm{Yb}: \mathrm{SZ}$ ceramics. Note, as detailed in the Fig. 1 caption, the samples with different $\mathrm{Yb}$ content $(5,10,15 \%)$ were treated at different temperatures and under different pressure values in order to determine the potential role of these parameters on the sintering process. In the case of nonprotonated ceramic pellets, no significant shrinkage is observed up to $1400^{\circ} \mathrm{C}$ as expected for a ceramic already sintered a few hours at $1450^{\circ} \mathrm{C}$. This thermal behavior is characteristic of all the nonprotonated $\mathrm{Yb}: \mathrm{SZ}$ ceramics investigated here and consequently does not depend on the $\mathrm{Yb}$ content.. On the contrary, protonated pieces, $\mathrm{H}^{+} \mathrm{Yb}: \mathrm{SZ}$, of the same ceramic pellets reveal the presence of significant shrinkage below $1400^{\circ} \mathrm{C}$. The most evident difference in the shrinkage temperature is observed as a function of autoclave treatment duration (Fig. 1a). Namely, the 10Yb:SZ ceramic treated either $24 \mathrm{~h}$ or $96 \mathrm{~h}$ at $250^{\circ} \mathrm{C}$ in autoclave (water pressure of $40 \mathrm{bar}$ ) exhibits a shrinkage starting either at 1200 or at $1000^{\circ} \mathrm{C}$, respectively. As it can be seen in Fig. $1 \mathrm{~b}$, the choice of the autoclave treatment temperature and pressure do not affect the shrinkage onset significantly. A slightly smaller shrinkage temperature is observed once the protonation process is performed at $200^{\circ} \mathrm{C}$ or $250^{\circ} \mathrm{C}$. Similarly, the $\mathrm{Yb}$ content has not very important role on the shrinkage phenomenon, only a small decrease of the shrinkage rate is observed when the $\mathrm{Yb}$ substitution is increased from 5 to $10 \%$. 
Figure 2 compares the thermal expansion/shrinkage curves recorded on the $1200^{\circ} \mathrm{C}$ - and $1300^{\circ} \mathrm{C}$ prefired $10 \mathrm{Yb}: \mathrm{SZ}$ porous ceramics, before and after protonation under $200^{\circ} \mathrm{C} / 15 \mathrm{bar} / 200 \mathrm{~h}$. Contrary to the pellet sintered at $1450^{\circ} \mathrm{C}$ (Fig. 1), the shrinkage of non-protonated pieces starts above $1300^{\circ} \mathrm{C}$ and reaches $\sim 2 \%$. In the case of protonated ceramics the shrinkage starts above $1000^{\circ} \mathrm{C}$ and reaches 7.5 and $8.2 \%$ for $1200{ }^{\circ} \mathrm{C}$ and $1300^{\circ} \mathrm{C}$ pre-fired pieces, respectively. The enhancement of densification is obvious and increases for porous, incompletely densified ceramics. The density reaches $90 \%$ for a $1400^{\circ} \mathrm{C}$ peak temperature.

\section{DISCUSSION}

The above results clearly show that the previous protonation treatment can decrease the onset of the sintering temperature. Different mechanisms can be at the origin of the sintering enhancement. The first one is related to the presence of secondary phases at the surface of protonated ceramics. Figures $3 \mathrm{a}$ and $3 \mathrm{~b}$ compare the Raman and IR spectra characteristic of $10 \mathrm{Yb}: S Z$ ceramic: non-protonated and protonated at $250^{\circ} \mathrm{C}$ under 40 bar of water vapor pressure. In the case of non-protonated compound, the spectra reveal the vibrational signature of the pure perovskite phase only. Note, from the vibrational point of view, the host perovskite structure can be considered as composed of two sublattices: the highly ionic network of Strontium cations and the covalently bonded $\mathrm{ZrO}_{6} / \mathrm{YbO}_{6}$ octahedra. Consequently, a low wavenumber region $\left(100-250 \mathrm{~cm}^{-1}\right)$ involves vibrations of the cationic network and the lattice modes, whereas the spectral range from 250 to $800 \mathrm{~cm}^{-1}$ reveals the bending and stretching modes of the covalent octahedron, respectively. After protonation, the presence of additional peaks/bands, easily detectable in Raman and IR spectra (Figs 3a, 3b), reveals clearly the formation of strontium carbonate and/or strontium hydroxide $[14,16]$. The $\mathrm{SrCO}_{3}$ can be identified by the fine, well resolved Raman peak $\left(\sim 1070 \mathrm{~cm}^{-1}\right)$ assigned to the stretching vibration of C-O bonds.

The $\mathrm{Sr}(\mathrm{OH})_{2}$ is especially well detected in the high wavenumber range, i.e. $\sim 3600 \mathrm{~cm}^{-1}$, in the form of a fine, single peak attributed to the vibration of isolated hydroxyl ions. As it can be seen in the IR spectrum, the $\mathrm{OH}$ signature is associatedwith the presence of the so called $\mathrm{ABC}$ bands which are assigned to the strong non-linear coupling of rapid $\mathrm{OH}$ and slow $\mathrm{O} \cdots \mathrm{O}$ modes. The second phase formation is due to the easy reaction between the alkaline earth elements with $\mathrm{H}_{2} \mathrm{O}$ and $\mathrm{CO}_{2}$. Achievement of the perfect stoichiometry is difficult and a priori a small alkaline earth excess is better/ 
less detrimental for undesirable modifications of the host perovskite phase than an excess of zirconium leading usually to zirconia second phase. The hydroxylation and carbonation are enhanced by the rather important active surface area and by the thermodynamic conditions. For instance, it is easier to create the carbonates if the protonation process is performed below $300^{\circ} \mathrm{C}$ [14].

Consequently, relatively high porosity of the $1200 / 1300^{\circ} \mathrm{C}$ pre-fired pellets and the protonation conditions $\left(200^{\circ} \mathrm{C} / 15\right.$ bar $\left.\mathrm{pH}_{2} \mathrm{O}\right)$ should promote the amount of strontium hydroxide/carbonate formed. According to the thermogravimetric analysis (Fig. 3c) hydroxide decomposition appears between 300$500^{\circ} \mathrm{C}$ whereas that of carbonate one is detected above $800^{\circ} \mathrm{C}$. These processes lead to the formation of $\mathrm{SrO}$ at the grain/pore surface that could promote the formation of a liquid film at the grain surface/interface. Note, the traces of $\mathrm{SrO}$ can be also detected by the presence of electronic transitions in the Raman spectrum arising from $4 \mathrm{f}$ ion interband luminescence emissions, excited by the laser beam (Fig. 3a) [31]. Such features are not observed on high dense ceramic pellets, free of any traces of second phases. Raman, IR and TG results point out that the sintering above $1000^{\circ} \mathrm{C}$ should be then due to the surface diffusion of $\mathrm{Sr}$ and $\mathrm{O}$ atoms. Melting of hydroxide before decomposition is possible [32] and this has been detected on similar material by conductivity measurement [33].

The second potential mechanism of enhanced sintering can be related to the behavior of oxygen vacancies. The alkaline earth perovskite structure exhibits oxygen vacancies due to the $\mathrm{Zr} / \mathrm{Yb}$ substitution. As previously established, the autoclave treatment allows filling preferentially the oxygen vacancies $\left(\mathrm{V}_{\mathrm{ox}}\right)$ close to the surface according to the reaction:

$\mathrm{H}_{2} \mathrm{O}+\mathrm{V}_{\mathrm{ox}}=>\mathrm{O}_{\mathrm{ox}}+2 \mathrm{H}_{\mathrm{i}}$

where $\mathrm{O}_{\mathrm{ox}}$ corresponds to an oxygen ion in its regular site and $\mathrm{H}_{\mathrm{i}}$ to an interstitial proton.

Note however, at the ceramic surface another reaction is more probable, namely the surface hydroxylation $\left(\mathrm{OH}_{\mathrm{s}}\right)$, summarized by the following equation

$\mathrm{H}_{2} \mathrm{O}+[$ ceramic $]=>\left[\right.$ ceramic $\left.+\mathrm{H}_{\mathrm{i}}\right] \mathrm{OH}_{\mathrm{s}}$ According to the second reaction the protonation leads to hydroxylation of the entire surface in contact with the water pressure and the material becomes rather similar to that prepared by hydrolysispolycondensation [26-28]. The de-hydroxylation enhances the oxygen surface diffusion and the sintering is driven by the surface diffusion. 
Diffusion of oxygen atoms/oxygen vacancies and interstitial protons is required to move vacancies from the bulk to the near surface region [34]. The local heterogeneities created by the protonation should enhance the bulk diffusion because of the gradient effect [35].

\section{CONCLUSIONS}

Sintering enhancement of perovskite ceramics after subsequent treatment under high water pressure is demonstrated. The sintering enhancement is assigned to the hydroxylation of the oxide surface maximized by the porosity of the pre-fired ceramic. The phenomenon seems to involve a combination of surface diffusion similar to that observed for oxides prepared by the hydrolysis-polycondensation of alkoxide sol-gel route plus the contribution of surface alkaline earth liquid film. The sintering enhancement offers new ways in the research field devoted to the control of the sintering temperature. Moreover, it can be very useful from a technological point of view since it seems to make the cosintering process easier. Further analyses, in particular of the pore surface and grain boundary interface, are however required to go deeper in the understanding of this new route promoting the low temperature sintering.

\section{ACKNOWLEDGMENTS}

The partners and partial financial support of French ANR PAN-H Celeva and H-PAC Heleva projects are acknowledged. Special thanks to Dr Béatrice Sala and Fréderic Grasset for many discussions. Mrs Elodie Tétard is kindly acknowledged for the preparation of the materials. 


\section{REFERENCES}

1. Forrat, F, Dauge G., Trevoux P., Danner G., Christan M., Electrolyte solide à base de l'application aux piles à combustible. Acad. Sci. Paris, 259 (1964), pp. 2813-2821

2. Iwahara H., Esaka T, Uchida H., Maeda N., Proton conduction in sintered oxides and its application to steam electrolysis for hydrogen production Solid State Ionics, 3/4 (1981), pp. 359-363

3. Colomban Ph. Ed.: Proton Conductors Solids, Cambridge University Press, Cambridge, 1992.

4. Ishihara T., Perovskite Oxide for Solid Oxide Fuel Cells. Springer, Dordrecht Heidelberg London New York, 2009.

5. Knauth Ph., Di Vona M.L., Eds.: Solid State Proton Conductors. Properties and Applications in Fuel Cells, John Wiley \& Sons, Chichester (2012)

6. Zheng Y., Zhou W., Ran R., Shao Z.P.., Perovskite as anode materials for solid oxide fuels cells, Progr. Chem., 20 (2008), pp. 413-421.

7. Geffroy P.M., Fouletier J., Richet N., Chartier T., Rational selection of MIEC materials in energy production processes, Chem. Engn Sci., 87 (2013), pp. 408-413.

8. Ni M., Leung M.K.H., Leung D.Y.C., Energy and exergy analysis of hydrogen production by solid oxide steam electrolyzer plant. Int. J. Hydrogen Energy, 32 (2007), pp. 4648-4660

9. Sala B., Lacroix O., Willemin S., Rhamouni K., Takenouti H., van der Lee A., Goeuriot P., Bendjeriou B, Colomban Ph., Procédé d'optimisation de la conduction ionique d'une membrane conductrice ionique, Patent WO 2008/152317 A2 (18-12-2008). Sala B., Grasset F., Lacroix O., Sirat A., Rahmouni K., Keddam M., Takenouti H., Goeuriot D., Bendjeriou B., Colomban Ph., van der Lee A., Sanchez J.G., Procédé de génération d'hydrogène et d'oxygène par électrolyse de vapeur d'eau, Patent FR 1159221 (12/11/2011); WO 2013053858 A1 (18/04/2013).

10. Sunarso J., Baumann S., Serra J.M., Meulenberg W.A., Liu, S. Lin, Y.S. da Costa J.C.D., Mixed ionic-electronic conductivity (MIEC) ceramic-based membranes for oxygen separation, J. Membrane Sci., 320 (2008), pp. 13-41.

11. Greenblatt M., Ruddlesden-Popper $\mathrm{Ln}_{n+1} \mathrm{Ni}_{n} \mathrm{O}_{3 n+1}$, nickelates: structure and properties. Solid state \& Materials Science, 2 (1997), pp. 174-183. 
12. Colomban Ph., Zaafrani O., Slodczyk A. Proton content and nature in perovskite ceramic membranes for medium temperature fuel cells and electrolysers. Membranes 2, (2012), pp. 493509.

13. Slodczyk, A., Colomban, Ph., Zaafrani, O., Lacroix, O., Loricourt J., Grasset F. Sala B. What is the true nature of conducting proton in perovskite ceramic membrane: hydroxyl ion or interstitial proton? MRS Proceedings, 1309 (2011) doi: 10.1557/opl.2011.616.

14. Colomban Ph.: Proton and Protonic Species: the Hidden Face of Solid State Chemistry. How to Measure H-Content in Materials? Fuel Cells, 13 (2013), pp. 6-18.

15. Slodczyk A., Zaafrani O., Sharp M.D., Kilner J.A., Dabrowski B., Lacroix O., Colomban Ph., Testing the chemical/structural stability of proton conducting perovskite ceramic membranes by in situ/ex situ autoclave Raman microscopy. Membranes, 3 (2013), pp. 311-330.

16. Colomban Ph., Tran C., Zaafrani O., Slodczyk A., Aqua oxyhydroxycarbonate second phases at the surface of $\mathrm{Ba} / \mathrm{Sr}$-based proton conducting perovskites: a source of confusion in the understanding of proton conduction. J. Raman Spectrosc., 44 (2013), pp. 312-320

17. Slodczyk A., Colomban Ph., Willemin S., Lacroix O., Sala B., Indirect Raman identification of the proton insertion in the high temperature $[\mathrm{Ba} / \mathrm{Sr}][\mathrm{Zr} / \mathrm{Ti}] \mathrm{O}_{3}$ modified perovskite protonic conductors. J. Raman Spectrosc., 40 (2009), pp. 513-521.

18. Slodczyk A., Colomban Ph., The structural and dynamics neutron study of proton conductors: difficulties and possible procedures, Eur. Phys. J. Special Topics, 213 (2012), pp. 171-193

19. Bendjeriou-Sedjerari B., Loricourt J., Goeuriot D., Goeuriot P., Sintering of $\mathrm{BaZrO}_{3}$ and $\mathrm{SrZrO}_{3}$ perovskites: role of substitutions by ytrium or yterbium, J. Alloys Compd, 509 (2011), pp. 61756183.

20. Perthuis H., Colomban Ph. Sol-gel Routes Leading to NASICON Ceramics, Ceramics Inter., 12 (1986), pp. 39-52.

21. Bouquin O., Perthuis H., Colomban Ph., Low Temperature Sintering and Optimal Physical Properties: a Challenge the NASICON Ceramics Case. J. Mat. Sci. Lett., 4 (1985), pp. 956-959.

22. Colomban Ph., Gel Technology in Ceramics, Glass-Ceramics and Ceramic-Ceramic Composites, Ceramics Inter.15 (1989), pp. 23-50. 
23. Colomban Ph., Nano/micro-structure and Property Control of Single and Multiphase Materials, in Chemical Processing of Ceramics, $2^{\text {nd }}$ Edition, Sridhar Komarneni and Burt Lee Eds, CRC Press Boca Raton, FI, USA, 2005 ch 12, 303-339

24. Perthuis H, Velasco G., Colomban Ph., $\mathrm{Na}^{+}$and $\mathrm{Li}^{+}$Nasicon Superionic conductor thin film, Jpn J. Appl. Phys., 23 (1984), pp. 534-543.

25 Collongues R., Gourier D., Kahn A., Boilot J. -P., Colomban Ph., Wicker A., $\beta$ Alumina, a Typical Solid Electrolyte: Latest Developments in Fundarnental Approach and in Battery Utilization. J. Phys. Chem. Solids, 45 (1984), pp. 981-1013.

26. Colomban Ph., Vendange V., Sintering of alumina and mullite prepared by slow hydrolysis of alkoxides : the role of the protonic species and of pore topology, J. Non-Crystalline Solids, 147 \& 148 (1992), pp. 245-250.

27. Bruneton E., Colomban Ph., Influence of hydrolysis conditions on crystallization, phase transitions and sintering of zirconias prepared by alkoxide hydrolysis, J. Non-Crystalline Solids $147 \& 148$ (1992) 201-205

28. Vendange V., Colomban Ph., Densification mechanisms of alumina, aluminosilicates and aluminoborosilicates gels, glasses and ceramics, J. Sol-Gel Sci. \& Techn., 2 (1994), pp. 407-411

29. Vendange V., Colomban Ph., How to tailor the porous structure of alumina and aluminosilicate gels and glasses, J. Matet. Res., 11 (1996), pp. 518-528.

30. Gouadec G., Colomban Ph., Slodczyk A., M. Pham Thi, Stress and Temperature driven phase transition in single crystalline KNbO3 and textured KNL-NTS ceramics: a Raman and thermal expansion studies, ISAF/IWATMD/PFM Conference 2014

31. Schmidt T., Dariz P., Shedding light onto the spectra of lime: Raman and luminescence bands of $\mathrm{CaO}, \mathrm{Ca}(\mathrm{OH})_{2}$ and $\mathrm{CaCO}_{3}$, J. Raman Spectrosc., 46 (2015), pp. 141-146.

32. Lechner R.E. Neutron investigations of superprotonic conductors. Ferroelectrics,167 (1995), pp. 147-167.

33. Jalarvo, N.; Haavik, C.; Kongshaug, C.; Norby, P.; Norby T. Conductivity and water uptake of $\mathrm{Sr}_{4}\left(\mathrm{Sr}_{2} \mathrm{Nb}_{2}\right) \mathrm{O}_{11}{ }^{*} \mathrm{nH}_{2} \mathrm{O}$ and $\mathrm{Sr}_{4}\left(\mathrm{Sr}_{2} \mathrm{Ta}_{2}\right) \mathrm{O}_{11}{ }^{*} \mathrm{nH}_{2} \mathrm{O}$. Solid State lonics, 180 (2009), pp.1151-1157.

34. Colomban Ph., Slodczyk A., Lamago D., André G., Zaafrani O., Lacroix O., Willemin S., Sala B., Proton Dynamics and Structural Modifications in the Protonic Conductor Perovskites, J. Phys. Soc. Jpn, 79 (2010), Suppl. A pp. 1-6. 
35 Philibert J., Adda Y., La diffusion dans les solides, INSTN-Presses Universitaires de France, Saclay, 1966.

\section{Figure Captions}

Fig. 1 : Thermal expansion/shrinkage curve of a) a $10 \mathrm{Yb}: \mathrm{SZ} 1450^{\circ} \mathrm{C}$-prefired pellet (np : as received, non protonated, treated $24 \mathrm{~h}$ or 96 at $250^{\circ} \mathrm{C}$, under 40 bar water pressure) ; b) the same pellet treated $96 \mathrm{~h}$ under different temperatures/water pressure values $\left(200^{\circ} \mathrm{C}: 15\right.$ bar, $250^{\circ} \mathrm{C}: 40$ bar, $300^{\circ} \mathrm{C}: 80$ bar): c) comparison of thermal expansion/shrinkage curve of $\mathrm{Yb}: \mathrm{SZ}$ ceramic pieces with different $\mathrm{Yb}$ content $(5,10$ or $15 \%)$ treated at $300^{\circ} \mathrm{C}$ under 80 bar for $96 \mathrm{~h}$.

Fig. 2 : Thermal expansion/shrinkage curve of $10 \mathrm{Yb}: \mathrm{SZ}$ ceramic pellets pre-fried at a) $1200^{\circ} \mathrm{C}$ and b) $1300^{\circ} \mathrm{C}$ (np : as received, non protonated; $\mathrm{H}+$, protonated at $200^{\circ} \mathrm{C} / 15$ bar for $200 \mathrm{~h}$ ).

Fig. 3: Raman (a), IR (b) and TGA (c) analyses of $10 \mathrm{Yb}: S Z$ ceramic in non-protonated (np) and protonated $\left(\mathrm{H}_{+}\right)$states. In the case of ceramics protonated at $250^{\circ} \mathrm{C}$ under 40 bar of water vapor pressure, the presence of carbonates $\left(\mathrm{CO}_{3}\right)$, electronic transitions $(\mathrm{TE})$ and hydroxides $(\mathrm{OH})$ is revealed by Raman and IR spectroscopy (peaks of $2^{\text {nd }}$ phases are marked by *). TG results show clearly departure of $\mathrm{H}_{2} \mathrm{O}\left(<100^{\circ} \mathrm{C}\right), \mathrm{OH}\left(<500^{\circ} \mathrm{C}\right), \mathrm{H}+\left(550-700^{\circ} \mathrm{C}\right)$ and decomposition of carbonates $\left(>800^{\circ} \mathrm{C}\right)$. 


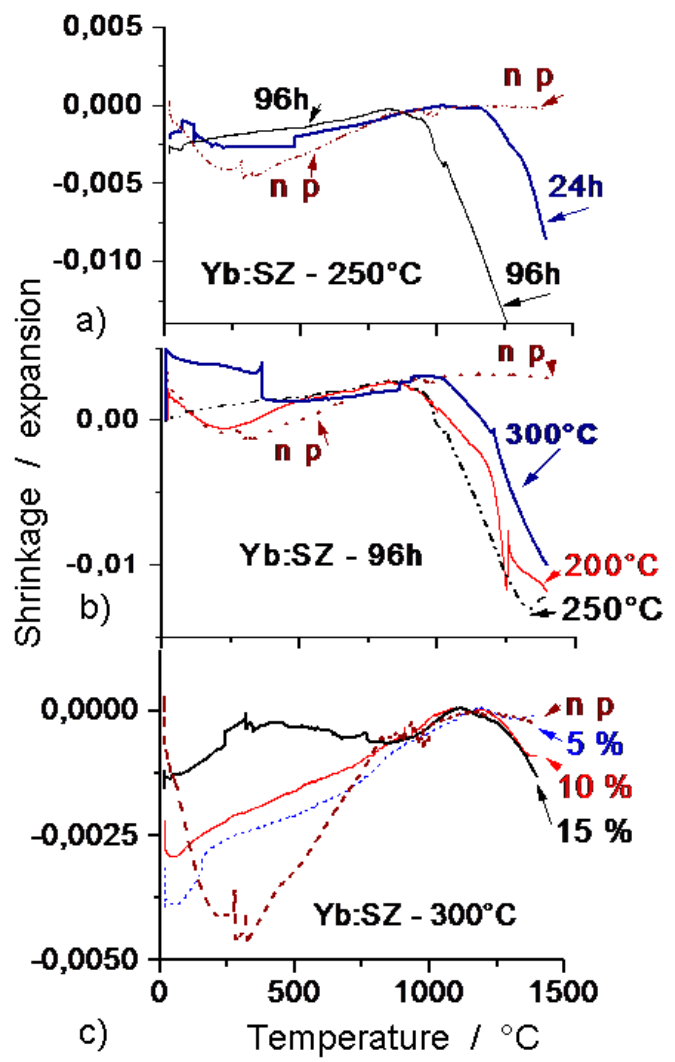

Fig. 1 : Thermal expansion/shrinkage curve of a) a $10 \mathrm{Yb}: \mathrm{SZ} 1450^{\circ} \mathrm{C}$-prefired pellet (np : as received, non protonated, treated $24 \mathrm{~h}$ or 96 at $250^{\circ} \mathrm{C}$, under 40 bar water pressure) ; b) the same pellet treated $96 \mathrm{~h}$ under different temperatures/water pressure values $\left(200^{\circ} \mathrm{C}: 15\right.$ bar, $250^{\circ} \mathrm{C}: 40$ bar, $300^{\circ} \mathrm{C}: 80$ bar): c) comparison of thermal expansion/shrinkage curve of $\mathrm{Yb}: \mathrm{SZ}$ ceramic pieces with different $\mathrm{Yb}$ content $(5,10$ or $15 \%)$ treated at $300^{\circ} \mathrm{C}$ under 80 bar for $96 \mathrm{~h}$. 


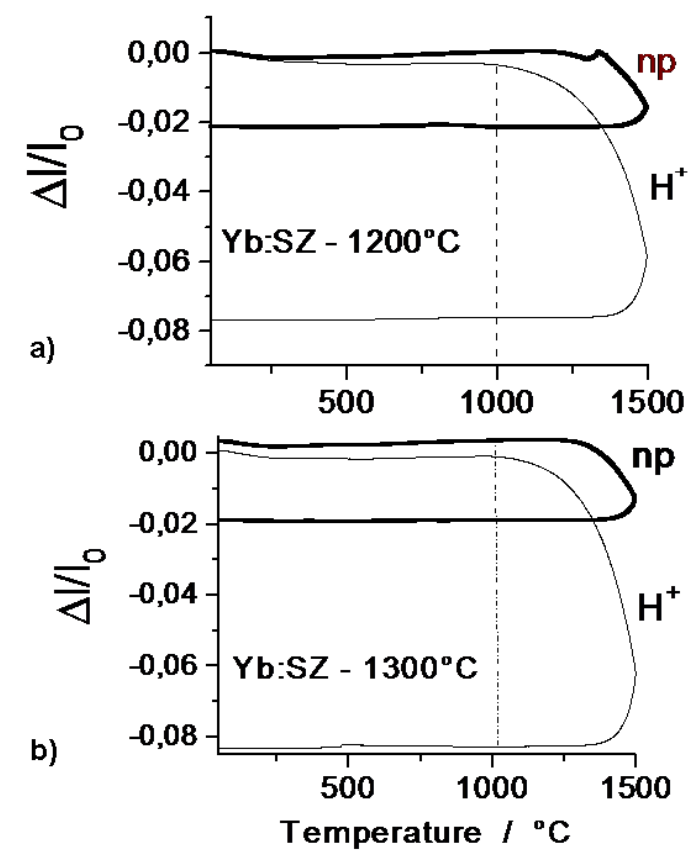

Fig. 2 : Thermal expansion/shrinkage curve of $10 \mathrm{Yb}: S Z$ ceramic pellets pre-fried at a) $1200^{\circ} \mathrm{C}$ and b) $1300^{\circ} \mathrm{C}$ (np : as received, non protonated ; $\mathrm{H}_{+}$, protonated at $200^{\circ} \mathrm{C} / 15$ bar for $200 \mathrm{~h}$ ). 

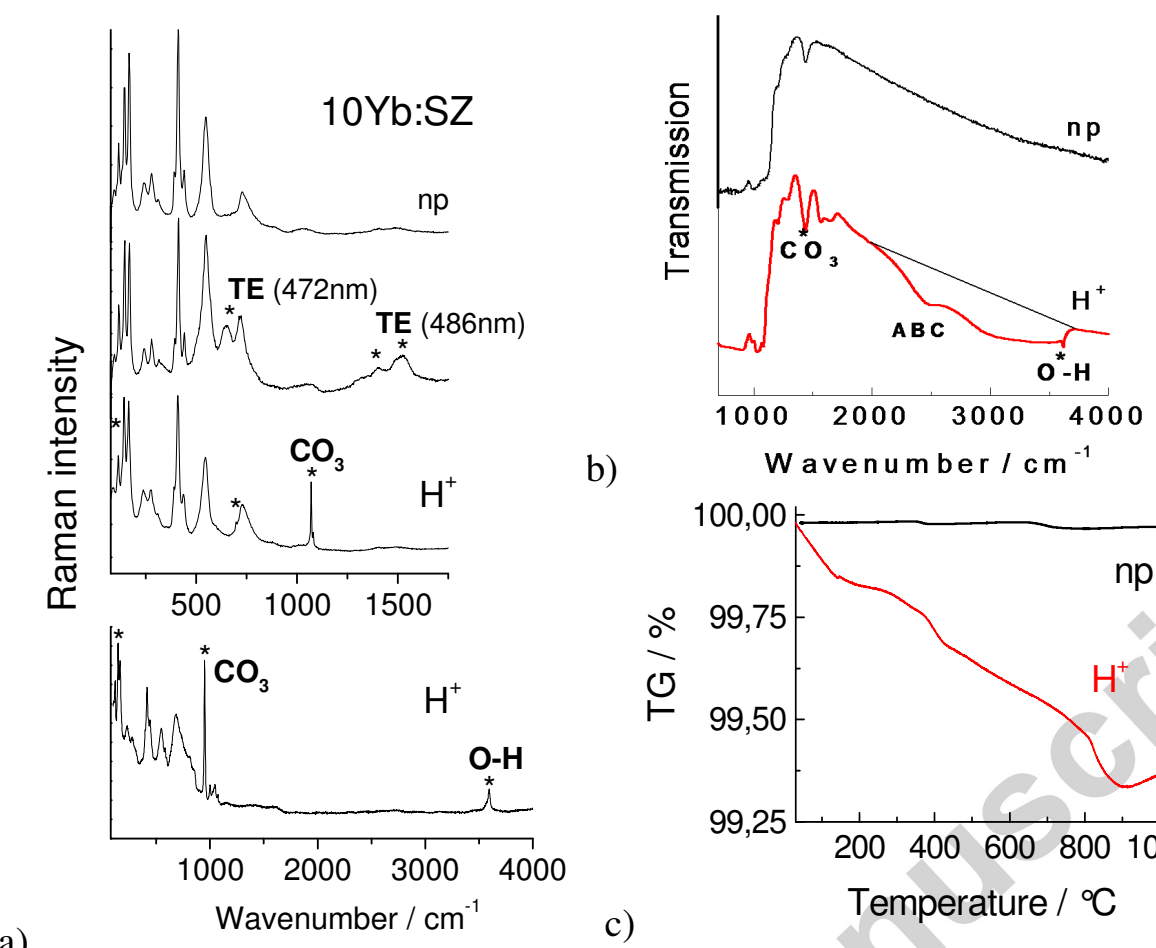

b)
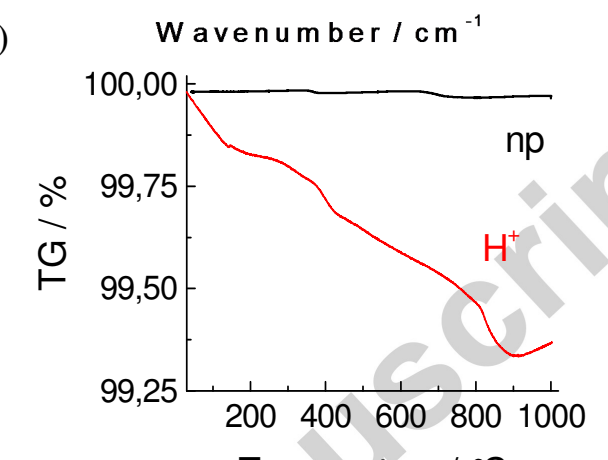

a)

c)

Temperature $/{ }^{\circ} \mathrm{C}$

Fig. 3: Raman (a), IR (b) and TGA (c) analyses of $10 \mathrm{Yb}: S Z$ ceramic in non-protonated (np) and protonated $(\mathrm{H}+)$ states. In the case of ceramics protonated at $250^{\circ} \mathrm{C}$ under 40 bar of water vapor pressure, the presence of carbonates $\left(\mathrm{CO}_{3}\right)$, electronic transitions $(\mathrm{TE})$ and hydroxides $(\mathrm{OH})$ is revealed by Raman and IR spectroscopy (peaks of $2^{\text {nd }}$ phases are marked by *). TG results show clearly departure of $\mathrm{H}_{2} \mathrm{O}\left(<100^{\circ} \mathrm{C}\right), \mathrm{OH}\left(<500^{\circ} \mathrm{C}\right), \mathrm{H}+\left(550-700^{\circ} \mathrm{C}\right)$ and decomposition of carbonates $\left(>800^{\circ} \mathrm{C}\right)$. 